\title{
Work Environment and Stress of Bank Employees
}

\author{
Anupa Kattil Prabhakaran, Rajandran KVR
}

\begin{abstract}
After the introduction of new economic policy in India, Banking sector has liberated itself from the traditional brick and mortar system and now it is incorporating changes for providing customer oriented service. Here easiness of conducting transactions is at the highest level for the customers but it overburdens the responsibilities and complexity of work, of bank employees. The work environment at the current day characterises deadlines at work, uncertainty of future, high competition and low social support, which has paved way for stressful condition for the employees. A sample of 75 bank employees were taken for the study from Kannur. Stress resulting from work environment are analysed in the study. The symptoms of stress could be rooted in psychological, physical or behavioural concepts. Though stress is a universal component in today's organisations, its symptoms and impact varies from person to person and this reflects on the outcome. The study aims at analysing the impact of demographic factors in instigating stress from the work environment. For the purpose, descriptive statistics, correlation, cross tabulation and Anova were used.
\end{abstract}

Index Terms: Occupational Stress, Work Environment,

\section{INTRODUCTION}

Indian banking is now moving along with international banking system with all its vibrance and competitive strength. With the multidimensional products the Indian banks are now addressing the varied type of customers globally. Such change, led to employees being the critical factor towards the execution and success of the banks. Thus the conventional working habits of Indian bank employee were metamorphosed with the new model. The result of this change brings heavy work and responsibility which ends with stress to them. There is nothing abnormal regarding stress at workplace. But stress is said to be excessive in nature when it interferes with employee's work productivity and performance, health - emotional \& physical and even their relationships. Organisations today try to bolster the well being of employees at workplace as their contribution determines the success and failure of the organisation. In pursuit towards a global economy banks have undergone enormous changes in the way they are organised. This reflects on the working life of the employees.

Revised Manuscript Received on July 05, 2019

Anupa Kattil Prabhakaran, Research Scholar, Periyar Maniammai Institute of Science \& Technology, Thanjavur, Tamil Nadu, India

Rajandran K.V.R, Associate Professor \& Head, Department of Management Studies, Periyar Maniammai Institute of Science \& Technology, Thanjavur - 613403, Tamil Nadu, India Work Overload

\section{LITERATURE REVIEW}

\section{A.Occupational Stress}

Occupational stress is the feature of job environment that creates a threat to the individual. It is the adverse environmental factor that is related to a certain job. Stress is a condition that exists due to the interaction of stressors at the work environment with the capabilities and characteristics of each individual [1].

\section{B. Work Environment}

Person-environment (P-E) fit perspective of stress states that the misfit between employee and his work environment results in stress which thereby leads to psychological and physiological strains [1]. When the work environment satisfies the employees in terms of money, support from superiors and colleagues, power and achievement, opportunity to satisfy needs for affiliation, there is said to be a good P-E fit. A match between job demands and the abilities of the employees also fosters P-E fit. Working environment is ignored by organisations in the pursuit for achieving success. It actually comprises of employees' safety, job security, relationships at the workplace, motivation and recognition for performance and participation in decision making. Once organisations provide emphasis on creating a good working environment, this would result in increasing the satisfaction and commitment of employees thereby reducing the stress experienced by them Spector.

Globalisation and the new economic policy have triggered significant changes in the work style and organisation structure of banks. As a result of this banks of the country have witnessed increase of more private and multinational banks which have led to stiff competition, mergers and acquisitions, mass layoff of staff which results in high job insecurity, outsourcing of banking operations and digitalisation to name a few, which tend to create stress among the employees. Constantly changing technology and modified organisation structures adds to the strain experienced by banking employees. Reports of the International Labour Organisation highlights the issues faced by the employees working in the financial services sector ie. Conflicting roles, relationship with customers, deadlines, work overload etc. Workplace is considered as a potential stressor for bank employees due to the extended duration spent interacting with customers of varied nature. 
Based on the analysis the purpose of the study is to identify the level of occupational stress of the bank employees and to find the role of work environment on occupational stress among the employees.

\section{METHODOLOGY}

Study was conducted among employees working in both public and private sector banks in Kannur, Kerala. Data were collected from a sample of 75 non-managerial employees. Certain components from the Occupational Stress Index developed by A.K.Srivastava and A.P. Singh were used for the Questionnaire. Likert's 5 point scale was adopted.

Work space or environment at work is said to be an important source of stress resulting from content, structural formations and the social relations at work. Intrinsic factors were identified as work overload, lack of variety at work, time pressure and complexity of tasks. The said factors with an inclination to generate stress at workplace were identified and taken as variables for the study.

Data was analysed with the following Hypothesis:

$\mathrm{H}_{0}$ : There is no significant difference in stress of the employee's and their gender, qualification and experience

\section{DATA ANALYSIS AND FINDINGS}

Reliability was tested using Cronbach Alpha, which gave a result of 0.68 , thereby identifying 6 strong variables for the study. (Table I)

Table I: Descriptive Statistics

\begin{tabular}{|l|c|c|c|}
\hline \multicolumn{1}{|c|}{ Variable } & N & Mean & $\begin{array}{c}\text { Standard } \\
\text { Deviation }\end{array}$ \\
\hline Excessive work on job & 75 & 4.12 & 0.85 \\
\hline $\begin{array}{l}\text { Lack of clarity in } \\
\text { information }\end{array}$ & 75 & 3.04 & 1.46 \\
\hline Fatigue due to workload & 75 & 3.49 & 1.19 \\
\hline $\begin{array}{l}\text { Work helps to enjoy a } \\
\text { good social status }\end{array}$ & 75 & 1.65 & 0.76 \\
\hline $\begin{array}{l}\text { Tendency to postpone } \\
\text { work }\end{array}$ & 74 & 2.85 & 1.28 \\
\hline Monotonous work & 75 & 3.72 & 0.94 \\
\hline
\end{tabular}

Table I shows the computing mean of the 6 variables, a lot of work to do on job ranked the highest, showing that overload of work was the most stressful factor at work. Monotony of work was the next factor considered.

Table II: Correlation among variables

\begin{tabular}{|c|c|c|c|c|c|c|}
\hline & $\begin{array}{c}\text { Exces } \\
\text { sive } \\
\text { work } \\
\text { on job }\end{array}$ & $\begin{array}{c}\text { Lack of } \\
\text { clarity } \\
\text { in } \\
\text { informat } \\
\text { ion }\end{array}$ & $\begin{array}{c}\text { Fatigu } \\
\text { e due } \\
\text { to } \\
\text { work1 } \\
\text { oad }\end{array}$ & $\begin{array}{c}\text { Work } \\
\text { helps } \\
\text { enjoy a } \\
\text { good } \\
\text { social } \\
\text { status }\end{array}$ & $\begin{array}{c}\text { Tenden } \\
\text { cy to } \\
\text { postpon } \\
\text { e work }\end{array}$ & $\begin{array}{c}\text { Mon } \\
\text { oton } \\
\text { ous } \\
\text { wor } \\
\mathrm{k}\end{array}$ \\
\hline $\begin{array}{c}\text { Excessive } \\
\text { work on } \\
\text { job }\end{array}$ & 1.00 & 0.40 & 0.46 & -.10 & -.01 & 0.28 \\
\hline
\end{tabular}

\begin{tabular}{|c|c|c|c|c|c|c|}
\hline $\begin{array}{c}\text { Lack of } \\
\text { clarity in } \\
\text { informati } \\
\text { on }\end{array}$ & 0.40 & 1.00 & 0.68 & 0.23 & 0.16 & 0.32 \\
\hline $\begin{array}{c}\text { Fatigue } \\
\text { due to } \\
\text { workload }\end{array}$ & 0.46 & 0.68 & 1.00 & 0.27 & 0.29 & 0.43 \\
\hline $\begin{array}{c}\text { Work } \\
\text { helps to } \\
\text { enjoy a } \\
\text { good } \\
\text { social } \\
\text { status }\end{array}$ & -.10 & 0.23 & 0.27 & 1.00 & 0.23 & -.02 \\
\hline $\begin{array}{c}\text { Tendency } \\
\text { to } \\
\text { postpone } \\
\text { work }\end{array}$ & -.01 & 0.16 & 0.29 & 0.23 & 1.00 & 0.09 \\
\hline $\begin{array}{c}\text { Monotono } \\
\text { us work }\end{array}$ & 0.28 & 0.32 & 0.43 & -.02 & 0.09 & 1.00 \\
\hline
\end{tabular}

Table II, shows that Work overload is positively correlated with lack of clarity on information regarding job role, fatigue at the end of the work day and monotony at job $(0.40,0.46$, 0.28 ). To perform at their best the communication at the workplace should be positive and clear. In this era of stiff cut throat competition, employees cannot restrict their performance to once functional area. In such a situation where banks undertake a multitude of operations, employees need to be briefed up clearly regarding their role and its outcomes. The absence of which creates stress in the employees. Overload at work can result in physical strain on the employee. Prolonged involvement in such nature of work can have a harmful impact on the health of the employees. Work overload and increased responsibility creates severe stress among the workers and managers. The nature of the work can also be a factor in instigating stress. Monotony at work can result in boredom and over a period of time can result in lack of interest at work. Being forced to do the same nature of work can exert strain on the employee. Result of the analysis shows that work overload is negatively correlated with social status. Social status is not an inclusive factor in connection with the job of a bank employee. It is also visible in the study that work overload is also negatively correlated with tendency to postpone work. Lack of clarity in communication regarding job is positively correlated with all the factors. It can be seen that employees tend to postpone their work due to this.

The data collected from the 75 sample respondents were recorded regarding how they perceive work environment as a stress factor. Calculating the mean and standard deviation of the consolidated score obtained, the employees were classified as Low stressed, Moderately stressed and Highly stressed based on mean $+/$ - standard deviation. Thus the level of stress of the bank employees were identified (Table III). Majority of the bank employees had moderate stress. Moderate stress is not an issue at present. But the reason for stress have to be identified and efforts are to be taken to ensure that their stress levels don't get converted to high levels in due course. The table also shows that $17 \%$ of the respondents were highly stressed. The banks are to address the issue at the earliest, as banks are the financial institutions, where hard earned money of the customers are to be transacted for their maximum benefits. 
Table III: Level of Stress

\begin{tabular}{|c|c|c|}
\hline Level of Stress & Frequency & \% \\
\hline Low & 13 & 17 \\
\hline Moderate & 49 & 65 \\
\hline High & 13 & 17 \\
\hline Total & 75 & 100 \\
\hline
\end{tabular}

To gain a detailed analysis, the association between demographic factors and the stress level of the employees were plotted through cross tabulation in Table IV. Gender wise analysis shows that majority have stress at moderate levels. Of the highly stressed category, majority (14.7\%) are male. PG holders are seen to be more stressed when compared to professionals and degree holders. Employees having more than 11 years of experience and above 35 years of age have stress only in moderate levels.

Table IV: Cross Tabulation

\begin{tabular}{|c|c|c|c|c|c|c|c|c|}
\hline \multirow{2}{*}{$\begin{array}{l}\text { Demogr } \\
\text { aphics / } \\
\text { Level }\end{array}$} & & \multicolumn{2}{|c|}{$\begin{array}{c}\text { Low } \\
\text { Stress }\end{array}$} & \multicolumn{2}{|c|}{$\begin{array}{c}\text { Moderate } \\
\text { Stress }\end{array}$} & \multicolumn{2}{|c|}{$\begin{array}{c}\text { High } \\
\text { Stress } \\
\end{array}$} & \multirow{2}{*}{$\begin{array}{c}\text { Tot } \\
\text { al } \\
\% \\
\end{array}$} \\
\hline & & $\mathbf{F}$ & $\%$ & $\mathbf{F}$ & $\%$ & $\mathbf{F}$ & $\%$ & \\
\hline \multirow[t]{2}{*}{ Gender } & Male & 7 & 9.3 & 23 & 30.7 & 1 & 14.7 & 54.7 \\
\hline & Female & 6 & 8 & 26 & 34.7 & 2 & 2.7 & 45.3 \\
\hline \multirow{3}{*}{$\begin{array}{l}\text { Qualific } \\
\text { ation }\end{array}$} & Degree & 4 & 5.3 & 15 & 20 & 3 & 4 & 29.3 \\
\hline & PG & 7 & 9.3 & 31 & 41.3 & 7 & 9.3 & 60 \\
\hline & $\begin{array}{c}\text { Professi } \\
\text { onal }\end{array}$ & 2 & 2.7 & 3 & 4 & 3 & 4 & 10.7 \\
\hline \multirow{4}{*}{$\begin{array}{c}\text { Experien } \\
\text { ce }\end{array}$} & $<5$ & 3 & 4 & 31 & 41.3 & 5 & 6.7 & 52 \\
\hline & $6-10$ & 7 & 9.3 & 13 & 17.3 & 8 & 10.7 & 37.3 \\
\hline & $11-15$ & 2 & 2.7 & 5 & 6.7 & - & - & 9.3 \\
\hline & $>16$ & 1 & 1.3 & - & - & - & - & 1.3 \\
\hline \multirow[t]{3}{*}{ Age } & Upto 25 & 1 & 1.3 & 24 & 32 & 5 & 6.7 & 40 \\
\hline & $26-35$ & 10 & $\begin{array}{c}13 . \\
3\end{array}$ & 19 & 25.3 & 7 & 9.3 & 48 \\
\hline & $36-45$ & 2 & 2.7 & 6 & 8 & 1 & 1.3 & 12 \\
\hline
\end{tabular}

The variables influencing stress in connection with work environment were identified and finalised on the basis of reliability value. To test the hypothesis Anova was carried out. All the tests showed the $\mathrm{p}$ value greater than 0.05 , by which the null hypothesis cannot be rejected. This shows that there is no significant difference in the stress experienced by the employees from work environment and their gender, education qualification and experience. In the present globalised scenario, the workings of the banks always creates stress and it will never be varied by any of the variables taken under study (Table V).

Table V: ANOVA

\begin{tabular}{|c|c|c|c|c|c|c|}
\hline & & $\begin{array}{l}\text { Sum of } \\
\text { Squares }\end{array}$ & df & $\begin{array}{c}\text { Mean } \\
\text { Squar } \\
\text { e }\end{array}$ & $\mathbf{F}$ & $\begin{array}{l}\text { Signif } \\
\text { icance }\end{array}$ \\
\hline \multirow{3}{*}{$\begin{array}{c}\text { Stress } \\
\text { from } \\
\text { Work } \\
\text { Environm } \\
\text { ent / } \\
\text { Gender }\end{array}$} & $\begin{array}{c}\text { Between } \\
\text { Groups }\end{array}$ & 20.58 & 1 & 20.58 & 1.23 & 0.27 \\
\hline & $\begin{array}{l}\text { Within } \\
\text { Groups }\end{array}$ & 1221.50 & 73 & 16.73 & & \\
\hline & Total & 1242.08 & 74 & & & \\
\hline \multirow{3}{*}{$\begin{array}{c}\text { Stress } \\
\text { from } \\
\text { Work } \\
\text { Environm } \\
\text { ent / } \\
\text { Qualificat }\end{array}$} & $\begin{array}{c}\text { Between } \\
\text { Groups }\end{array}$ & 64.52 & 2 & 32.26 & 1.97 & 0.15 \\
\hline & $\begin{array}{l}\text { Within } \\
\text { Groups }\end{array}$ & 1177.56 & 72 & 16.35 & & \\
\hline & Total & 1242.08 & 74 & & & \\
\hline
\end{tabular}

\begin{tabular}{|c|c|c|c|c|c|c|}
\hline ion & & & & & & \\
\hline \multirow{3}{*}{$\begin{array}{c}\text { Stress } \\
\text { from } \\
\text { Work } \\
\text { Environm } \\
\text { ent / } \\
\text { Experienc } \\
\text { e }\end{array}$} & $\begin{array}{c}\text { Between } \\
\text { Groups }\end{array}$ & 114.24 & 3 & 38.08 & 2.40 & 0.08 \\
\hline & $\begin{array}{l}\text { Within } \\
\text { Groups }\end{array}$ & 1127.84 & 71 & 15.89 & & \\
\hline & Total & 1242.08 & 74 & & & \\
\hline
\end{tabular}

\section{V.CONCLUSION}

The new economic policies have widened the nature of operations of the banking sector, which have influenced the working environment in banks. Competitions among the players in the sector, add on services, customer mobilisation and high technology enabled operations have complicated the employees performance. The study shows that the work environment at the bank is a factor that instigates stress among the employees. The level of stress though not alarming at present, could end up harmfully if proper measures are not taken by the management.

\section{REFERENCES}

1. A. K. Srivastava, Management of Occupational Stress Theories and Practice. Gyan Publishing House, 1999.

2. R. Neelamegam \& S. Asrafi., "Work stress among employees of Dindigul District Central Co-operative Bank, Tamil Nadu: A Study". Journal of Management Research. 9:57-69, 2010.

3. Petarli G.B., Zandonade E., Salaroli L.B. \& Bissoli N.S., "Assessment of occupational stress and associated factors among bank employees in Vitoria, State of Espirito Santo, Brazil"

4. Giorgi G., Arcangeli G., Perminiene M., Lorini C., Ariza-Montes A., Fiz-Perez J., Di Fabio A. \& Mucci N., "Work-related stress in the Banking sector: A review of incidence, correlated factors and major consequences" Front Psychology, 8:2166, 2017.

5. Kaur K., Kaur P. \& Kumar P., "Stress, coping mechanisms and its socio economic impact on organisations - A review". Indian Journal of Economic Development. 13, 744 - 751, 2017.

6. Hassard J., Teoh K.R., Visockaite G., Dewe P. \& Cox T., "The cost of work-related stress to society: a systematic review". Journal of Occupational Health Psychology [ Epub ahead of print ], 2017.

7. Khattak K., Khan A., Haq, Arif \& Minhas A., "Occupational stress and burnout in Pakistan's banking sector". African Journal of Business Management. 5(3):810-817, 2011.

8. Malik N., "A Study on occupational stress experienced by private and public bank employees in Quetta City". African Journal of Business Management. 5 (8):3063-3070, 2011. 